\title{
Organizational learning and market performance: The interactive effect of market orientation
}

\author{
Moses Tahate Kamya \\ Department of Marketing and International Business, Makerere University Business School, Kampala, Uganda. \\ E-mail: kamyamt@yahoo.co.uk or mkamya@mubs.ac.ug. Tel: +256-752 - 836-736. \\ Accepted 15 May, 2012
}

\begin{abstract}
This study examines the interactive effect of market orientation in the relationship between organizational learning and market performance. Market performance, as the dependent variable, is expected to create wealth for organizations and shareholders, however, so far, little empirical attention has been given to market performance as one of the decisive end outcome of organizational learning activities. Using a cross-sectional survey design, the empirical findings indicated a positive relationship between the study variables. A continuum among the organizational learning styles (adaptive learning, generative learning and triple-loop learning) was established with market performance. Market performance is greatly improved when organizational learning interacts with market orientation and the discussion focuses on managerial support, an appropriate learning infrastructure and market-based organizational culture as the foundations for the relationships in the organizations.
\end{abstract}

Key words: Organizational learning, learning styles, market orientation, market performance, management practices.

\section{INTRODUCTION}

Organizational learning has become a key resource for improving organizational performance (Akgün et al., 2003; Hoe and McShane, 2010; Jiménez-Jimenez et al., 2008; Jyothibabu et al., 2010) as companies with the capacity to learn faster are likely to respond to market challenges better than competitors. According to Chang and Ahn (2005) business (firm) performance is inclusive of both organizational performance and market performance; where market performance is a measurement system that is expected to cover all aspects of organizational performance in the market place while organizational performance is an internal or employeefocused performance. The purpose of this study is to focus on market performance as one of the end outcomes of organizational learning.

The benefits of organizational learning are expected to be embedded and manifested in the products and services offered whereby customer value is tested in the marketplace in terms of customer reaction. As the competitiveness and survival in the market continue to depend on customer reaction, we contend that this relationship should be of interest to organizations that practice organizational learning. Furthermore, we argue that implementing market orientation is a learning process which bears much of the seminal work of Senge (1990), and Bui and Baruch (2010).

Review of literature shows that empirical studies on organizational learning have concentrated on organizational performance outcomes other than market-based performance outcomes. For example, empirical study by Politis (2005) focused on work outcomes such as productivity; also a study by Yeo (2003) on the relationship between organizational learning and performance indicated internal performance outcomes such as employee attitudes, motivation and commitment. Even the study by Yang (2007) on organizational learning emphasized internal performances. We, therefore, put it that existing empirical explanations of how organizational learning relates to market performance are incomplete especially if learning is expected to create wealth for organizations and shareholders.

The bottom-line is that as an organization learns to make sense of its markets, market-based information, such as customer-based behaviors, is expected to create 
outcomes that are manifested in its market performance (O'Keeffe and Harington, 2001). For instance, according to McGuinness and Morgan (2005) and Wang and Ahmed (2003), consumers' reaction as to how best an improvement can be successful has to be sought if organizational learning is expected to cause a change in market performance especially at consumer level. Also in line with the institutional theory the rate at which an organization learns need to be better than competitors if changes in the marketplace are to be expected; and at least in line with market changes in order to cause an impact in the market place (Saru, 2007; Konidari and Yvan, 2006).

Organizations have to develop the capability to tap and learn from market-based information that resides in stakeholders who include customers, competitors, channel members and suppliers so that appropriate responses are made at the right time (Hoe and McShane, 2010; Werr et al., 2009). In this case, an organization has to continuously adapt to the market environment which requires a market orientation approach. Market orientation is explained in the context of implementing the marketing concept that focuses on satisfying customer needs better than competitors (Racel et al. 2007; Mason and Harris, 2006; Zhou et al., 2009).

Market orientation includes acquiring data, processing that data and analyzes information on customers, competitors and society in general. Organizations are expected to learn from that knowledge in order to achieve superior market-based outcomes. As a result market orientation contributes to the attainment of a sustainable competitive advantage by learning what customers need, want and deliver customer value, examine and proactively counter current and potential competitors; and adjust to market trends with appropriate customer value offerings (Day, 1994; Hunt and Morgan, 1995).

\section{LITERATURE REVIEW AND HYPOTHESIS DEVELOPMENT}

\section{Organizational learning and market performance}

Empirical research on the link between organizational learning and market performance is still scare. However a significant body of literature emphasizes that organizational learning is a strong source for gaining competitive advantage which in turn implies achieving better organizational performance.

Garnett et al. (2008), Hancott (2005) and Schiuma and Lerro (2008) noted that a good number of variables have been used in measuring organizational performance which include profitability measures, shareholder return, return on sales, number of new products, return on assets, return on capital, return on sales and others.

A study by Steer (1975) identified three dimensions of measuring organizational performance: financial performance, business performance and organization effectiveness, on the other hand Delaney and Huselid (1996) has market performance as a distinctive measuring variable for organizational performance.

In this study we emphasize the importance of organizational learning in influencing market performance in terms of: financial performance since the financial component of an organization is much a result of customer buying, market growth which is expected to be attained if positive learning has taken place in the organization and customer satisfaction implying that the organization has successful learnt to manage and implement the marketing concept. In this case the fundamental argument is that for organizational learning to be a source of profitability, competitiveness and survival for an organization it has to be translated into market-based outcomes that measure market performance. This means that employees are committed and open to learning (Prugsamatz, 2010) which ultimately improves the organization's competitiveness and performance in the market place.

Furthermore the relationship between organizational learning and market performance enables the organization to be proactive in sensing trends and events in the market place (Day, 1994; Tippins and Soh, 2003). The relationship enhances the questioning and review of the norms and values of the organization in order to adjust to market trends. Among the obstacles to organizational learning is motivating employees to learn by sharing knowledge and to encourage them to abandon what they currently have as successful working practices and beliefs for new ones which may be considered risky.

Argyris and Schon (1978; 1996) and Senge (1990) established two types of organizational learning: adaptive learning (single-loop learning) and generative learning (double-loop learning). Adaptive learning is about making better the existing rules, enhancing efficiency and improving the existing strategies, without tapering with the norms and beliefs of the organization. In this case when an error is detected and corrected there is no questioning or altering the underlying values of the system (Argyris, 1999) since it occurs within the context of existing mental models (Akgün et al., 2003; Argyris and Schon, 1978; Slater and Narver, 1995).

Consequently, if there is any fault with the existing mental models, adaptive learning can lead to non-optimal market performance. Adaptive learning is regarded as the lowest level of learning in that even if habits are learned there is still resistance to both change and future learning which does not stop the error or problem to happen again (Burgoyne, 1995).

Generative learning (double- loop learning) promotes inquiry, challenges current assumptions and cause new theories-in use (Argyris and Schon, 1996). Generative learning redefines the current values, beliefs and norms focusing on enabling strategic renewal and transformation. Errors are questioned constructively as well as 
why or how successes occur and in this way learning takes place when mismatches are corrected by first examining and altering the governing variables and then the actions (Argyris, 1999; Marquadt, 1996). This type of learning is basically intuitive and tacit in nature requiring a higher level of constructive foresight and rethinking. According to Senge (1990) this level of learning is about creating rather than coping.

Building on adaptive learning and generative learning, is the triple-loop learning as the highest level of organizational learning. At this level of learning there is constant questioning and re-examination of current norms, beliefs, values, products, processes and systems as to how they promote the organization in the future market place (Kuada, 2010; Wang and Ahmed, 2003). Wright et al. (1995: 51) observed that "despite the firms resources and capacities having added some value in the past, changes in customers' demands, in industry's structure or in technology may turn them into less valuable in the future. This observation is in line with triple-loop learning and therefore the continuous challenge and assessment of those fundamental variables becomes the source of innovation for the organization. At this level the mental models are not blocked and are not even kept within the current experiences and practices only; but open-up to accommodate new mental models that competitively propel the organization in the long-run (Bui and Baruch, 2010; Weldy and Gillis, 2010). When an organization successfully implements the triple-loop learning, it starts "to see patterns where others see only events and forces to react to" (Senge, 1990: 73). From the previous discussion we hypothesis as follows:

$\mathbf{H}_{\mathbf{1}}$ : There is a positive relationship between organizational learning and market performance.

$\mathbf{H}_{\mathbf{2}}$ : Every organizational learning style (a) adaptive learning, (b) generative learning and (c) triple-loop learning, adds to the prediction of market performance.

\section{The interactive effect of market orientation}

Literature review on market orientation emphasizes its importance in obtaining information about customers, competitors and market trends. It enables the organization to acquire new knowledge and anticipate the needs of its current and future customers. This new knowledge becomes the base for challenging the current assumptions, beliefs and values leading to learning.

Market orientation scholars have over time agreed that for market orientation to have an impact on performance firms need to develop their ability to learn generatively, to address latent needs and create customer value (Day, 1994, 1999; Kohli et al., 1993; Jaworski et al., 2000; Slater and Narver, 1995, 1999). Within this line of thinking, Baker and Sinkula (1999) and Jiménez-Jimenez et al. (2008) add on that a strong market orientation must be complemented by a strong learning orientation to optimize the ability of firms to engage in both adaptive and generative learning activities.

Market orientation is a necessary condition for organizational learning as market information is transformed into knowledge. Slater and Narver, (1995) argue that managers seeking to maximize organizational learning need to know how to develop efficient market information through market orientation activities

Most of the studies to date, that have been carried out on market orientation have been based upon the five different perspectives developed by Shapiro (1988), Kohli and Jaworski (1990), Narver and Slater (1990), Ruekert (1992) and Deshpande et al. (1993). Recently, the capability perspective has been proposed by Foley and Fahy $(2009,2004)$. This perspective is based on the understanding that market orientation has positive relationships with a number of capabilities such as customer-linking capability (Hooley et al., 2005) and the market-sensing capability (Day, 1994). Market-sensing is a pre-emptive capability which enables the firm to track and learn how the market is moving in advance of its competitors. This is through an open approach to market information development and interpretation, leading to the capture of market insights as characterized by activities such as scanning outside the periphery or seeking insights beyond the usual sources (Menguc and Ash, 2006; Olavarrieta and Friedmann, 2007).

Shapiro (1988) conceptualized market orientation as an organizational decision-making process starting from information up to implementation. The major elements of this process are a strong commitment by management to share market-based information interdepartmentally and to practice open decision-making between functional and divisional employees. With this perspective, markets and customers must be understood, information has to permeate into every corporate function, it is important to develop the ability to make strategic and tactical decisions, decisions must be well co-ordinate, and the strength and weaknesses of competitors must be understood.

Kohli and Jaworski, (1990) developed the intelligence perspective of market orientation. In this perspective market orientation is viewed as the implementation of the marketing concept, and is a mixture of three activities: organization of market intelligence pertaining to current and future needs of the customer, dissemination of intelligence within the organization and also responsiveness to the information obtained.

The strategic focus perspective by Ruekert, (1992) presented the market orientation as the degree to which a strategic business unit obtains, learns and uses information regarding its customers, develops a strategy considering the obtained information about customer needs, satisfaction and implements that strategy meeting those needs and wants. 
Ruekert (1992) borrowed information and responsiveness aspects of his perspective from Kohli and Jaworski (1990) and Narver and Slater (1990). This perspective focused on the business unit in an organization (identifying market orientation in each unit of an organization) rather than the whole organization or individual market as the unit of analysis.

Deshpande et al. (1993) developed the customer orientation perspective. They proposed that in order to achieve a long-term profitable venture, an organization should put the customer' interest first, while not excluding all the stakeholders such as owners, managers and employees. Deshpande et al. (1993: 27) further noted that, "we see customer orientation as being a part of an overall, but much more fundamental, corporate culture".

The perspective of Deshpande, Farley and Webster makes use of the cultural perspective of Narver and Slater (1990). In this regard organizational learning and market orientation are mutually dependent and synergistic related in enhancing market performance (Bell et al., 2008; Baker and Sinkula, 2002). Based on the previous discussion, organizational learning can influence market performance through the mediation of market orientation, therefore we hypothesize that:

\section{$\mathbf{H}_{3}$ : The interaction effect between organizational learning and market orientation improves market performance.}

\section{METHODOLOGY}

\section{Research setting and procedure}

A cross-sectional survey design examined the relationship between organizational learning and market performance with the interaction of market orientation. A self-administered survey questionnaire was used to collect data. Questionnaires were anonymously completed and data confidentiality assured. A questionnaire was developed on the three study constructs using measurement scales derived from previous empirical studies which were modified to suite the study location.

The questionnaire was screened by experts/professionals with whom a series of personal interviews were undertaken and basing on their expert comments, some items were removed due to lack of conceptual relevance. After this step, a second version of the questionnaire was presented to another group of experts/ professionals who were requested to rate the relevance of each measurement item. Taking into consideration the comments of the experts/professionals the instrument was further refined and a pilot study conducted on a sample of 60 organizations to evaluate the reliability and validity of the measurement. A content validity index of 0.7 and over was obtained from the pilot study.

The participating firms were approached and requested to participate in the study. One respondent at senior level or middle level management from each of the participating organizations was contacted in person to fill in the questionnaire. We chose to use senior or middle managers as unit of inquiry because they are seen as having a wide breadth of knowledge of all the organization's functions, activities and operating environment (Frost et al., 2002; Hillman and Keim, 2001). This is consistent with Westphal and Frederickson (2001), Chattopadhyay et al. (1999), and Spanos and Lioukas (2001) who also agree that top management has a significant impact on strategic direction and change.

\section{Sampling and sample characteristics}

The sampling frame for the study was based on the Uganda Bureau of Statistics (UBOS) - Business Register 2006/07. The report indicated a population of 11,153 organizations in Kampala region from which a sample size of 718 firms (manufacturing sector 324 firms and service sector 394 firms) was established using Krejcie and Morgan (1970) table. After establishing the sample size for every industry in the stratum, a purposive sampling method (judgemental sampling) was used to select the responding firms using the sample frame obtained from UBOS. Of the 494 returned questionnaires, 483 were usable questionnaires (67.2\%) and were analyzed for the study. 11 questionnaires were unusable (8 were inconsistently answered and 3 were incomplete).

Demographic characteristics of the sample firms and firm respondents show that both manufacturing and service sectors were adequately presented (45.8 and 54.2\%, respectively). Numbers of employees and annual turnover indicate that the study covered the basic divisions of firms in Uganda namely small-scale enterprises (maximum of 50 employees and an annual income below shillings.100 million), medium-size enterprises (employing between 50 to100 workers with an annual income exceeding shillings. 360 million) and large firms (with more than 100 employees). Organizational tenure indicated that $93.6 \%$ had operated in Uganda for more than 5 years, $97.1 \%$ of firm respondents were in positions of departmental managers and above, and $97.8 \%$ were holders of PhDs (3.1\%), Master's degrees $(28.5 \%)$, professionals $(21.9 \%)$ and Bachelor's degrees $(44.3 \%)$. Over $73.5 \%$ of firm respondents had worked for over 4 years with their respective firms. All the firms are in the private sector located in and around Kampala the capital city of Uganda a developing country in the East African region.

\section{Measurement, validity and reliability}

The questionnaire comprised of two sections. The first section captured data on the organization profile and that of firm respondents. This was followed by organizational learning as a function of adaptive learning, generative learning and triple-loop learning while market performance covered financial performance, market growth and customer satisfaction. Market orientation covered customer orientation, competitor orientation and interfunctional coordination. Measurements scales were based on previous empirical studies and modified to fit into the local situation.

All item scales were anchored on a five point scale with $5=$ 'strongly agree', 4 = 'agree', 3 = 'neither agree nor disagree', 2 = 'disagree' and $1=$ 'strongly disagree'. The scale reliability values (Cronbach alpha) for all components were greater than 0.7 which is the minimum acceptable level suggested by Neuman (2006) and Nunnally $(1978,1967)$.

Organizational learning scales were derived from the works of Bennett (1998); Chaston et al. (1999); Mostafa (2005) and SadlerSmith et al. (2003). This yielded a reliability Cronbach alpha coefficient of 0.898 . Item scales for market orientation were derived from Narver and Slater (1990) and Narver et al. (2004) and yielded an overall reliability of Cronbach alpha coefficient 0.862 . Market performance scales were adapted from the empirical research works of Shoham et al. (2005), Narver and Slater (1990) and Narver et al. (2004), yielding an overall Cronbach alpha coefficient of 0.894 .

\section{Control variables}

Type of industry, number of employees and organizational tenure were introduced in the hierarchical regression models as control variables. It would give an erroneous picture if they are not 
Table 1. Zero-order correlations matrix.

\begin{tabular}{lccccc}
\hline Parameter & Means & St. dev & $\mathbf{1}$ & $\mathbf{2}$ & $\mathbf{3}$ \\
\hline Organizational learning (1) & 3.79 & 0.533 & 1.00 & & \\
Market orientation (2) & 3.91 & 0.627 & $0.442^{\star *}$ & 1.00 & \\
Market performance (3) & 3.85 & 0.814 & $0.476^{\star *}$ & $0.697^{\star *}$ & 1.00 \\
\hline
\end{tabular}

** Correlation is significant at the 0.01 level (2-tailed): $\mathrm{N}=483$. Source: Primary data.

Table 2. Hierarchical regression of the predictive power of each organizational learning strategy (adaptive learning, generative learning and triple-loop learning) on market performance.

\begin{tabular}{lcccc}
\hline Variable & Model 1 & Model 2 & Model 3 & Model 4 \\
\hline Constant & $4.86^{\star *}$ & $4.88^{\star *}$ & $4.29^{\star *}$ & $2.88^{\star \star}$ \\
Type of industry & $-0.092^{\star *}$ & $-0.092^{\star \star}$ & -0.078 & -0.028 \\
Number of employees & $-0.335^{\star *}$ & $-0.336^{\star *}$ & $-0.273^{\star *}$ & -0.100 \\
Organizational tenure & $0.172^{\star *}$ & $0.173^{\star *}$ & $0.135^{\star *}$ & 0.063 \\
Adaptive learning & & 0.002 & -0.001 & 0.000 \\
Generative learning & & & $0.267^{\star *}$ & 0.047 \\
Triple-loop learning & & & & $0.600^{\star *}$ \\
R & 0.356 & 0.356 & 0.440 & 0.673 \\
R square & 0.127 & 0.127 & 0.194 & 0.453 \\
Adjusted R square & 0.121 & 0.120 & 0.185 & 0.446 \\
F - statistics & 23.1 & 17.3 & 22.9 & 65.8 \\
R Square Change & 0.127 & 0.000 & 0.067 & 0.260 \\
F change-statistics & 23.1 & 0.05 & 39.5 & 326.1 \\
Sig & 0.000 & 0.820 & 0.000 & 0.000 \\
Sig F Change & 0.000 & 0.000 & 0.000 & 0.000 \\
\hline
\end{tabular}

$\mathrm{n}=438$ Standardized regression coefficients are reported. ** ${ }^{*}$ gression is significant at the 0.01 level, * regression is significant at the 0.05 level.

controlled; for instance we believe that some industries may be given preferential treatment by government policy (Briggs, 2009) or by virtue of geographical location which enhances their competitive advantage. Firms with many employees and higher annual turnover are expected to have the capability in developing superior competitive advantages (Briggs, 2009). We also expect that for some firms staying long in a certain environment enhances their chances to build superior competitive advantage.

\section{RESULTS}

Table 1 indicates that organizational learning significantly and positively correlate with market performance $(r=$ $0.476, p<0.01$ ) which supports hypothesis $H_{1}$. This relationship indicates that organizational learning is a positive function of market performance and as mentioned before there is lack of confirming empirical evidence where the dependent variable is market performance. However, the results indicate what has been widely conceptualized in literature that organizational learning improves organizational performance in its wide application. Therefore, taking a general position of organizational performance (which may or may not include market performance) the results of this study are supported by previous studies that found a positive relationship between organizational learning and performance (Bontis et al., 2002; Ellinger et al., 2002; Michna, 2009; O'Keeffe and Harington, 2001; Tippins and Sohi, 2003; Whittington and Dewar, 2004; Yeo, 2003). The contribution of organizational learning $(47.6 \%)$ to market performance reflects its importance and Brockmand and Morgan (2003), Dixon (1992), Dodgson (1993), and Nevis et al. (1995) refer to organizational learning as a critical competence for achieving superior performance. Firms with such competence are expected to learn faster and are better prepared for future challenges than competitors (Day, 1994). Yeo (2003) found out that the positive relationship is a result of a collective effort of both individual learning and team leaning which he referred to as subsets of organizational learning.

Table 2 establishes the extent to which adaptive learning, generative learning and triple-loop learning are 
important in influencing market performance, respectively. The results show the $R$ squared change at each step of the regression as well as the significance of the beta weights for each variable in each model.

In model 2 adaptive learning accounted for $0.000 \%$ variance in market performance $\left(\Delta R^{2}=0.000\right)$ causing a statistically non significant standardized coefficient $(B=$ $0.002, p<0.01)$. This is an indication that adaptive learning style do not foster significant positive changes in market performance, $\mathrm{H}_{2 \mathrm{a}}$ is not supported.

In Model 3, generative learning was introduced in the regression model and it contributed an additional $6.7 \%$ variance in market performance $\left(\Delta R^{2}=0.067, p<0.01\right)$ resulting in a statistically significant standardized coefficient $(B=0.267, p<0.01)$, supporting $\mathrm{H}_{2 b}$. When triple-loop learning was introduced in Model 4 , it made an additional $26.0 \%$ variance in market performance $\left(\Delta R^{2}=\right.$ $0.260, p<0.01)$, resulting in a statistically significant standardized coefficient $(B=0.600, p<0.01)$ and supporting $\mathrm{H}_{2 \mathrm{c}}$.

The standardized beta values in Models 2 to 4 give an insight in the form of a continuum among these three organizational learning styles, starting from the adaptive learning style a low-level learning stage with nonsignificant effect on market performance, through generative learning style with significant effect on market performance to triple-loop learning style with a higher significant effect on market performance. It is observed that in model 4 when the triple-loop learning a higherorder learning style is introduced in the model even the generative learning style stops to be significant.

It was hypothesized $\left(\mathrm{H}_{3}\right)$ that market performance is improved when organizational learning interacts with market orientation. To test $\mathrm{H}_{3}$ four multiple hierarchical regressions were conducted as shown in Table 3.

The results in Table 3 show that organizational learning and market orientation accounted for 13.5 and $9.3 \%$ of variance in market performance, respectively $\left(\Delta R^{2}=\right.$ $0.135 \mathrm{p}<0.01$ and $\Delta \mathrm{R}^{2}=0.093 \mathrm{p}<0.01$ ). More empirical findings have emphasized that organizational learning is a critical competence and a major asset for organizational performance (Ho, 2008; Jiménez-Jimenez et al., 2008; Lei et al., 1996; Subramanian et al., 2009). It is also market-based knowledge that is very much needed by an organization in its efforts to offer value to customers.

Model 4 show that when the two-way interaction term [Organizational learning* market orientation (OLxMO)] was introduced in the model, it contributed an additional $16.0 \%$ of the variance in market performance $\left(\Delta R^{2}=\right.$ $0.160, p<0.01$ ) supporting $H_{3}$. The main effects (organizational learning, market orientation and the interaction term) accounted for $49.1 \%$ variance in market performance $(R$ squared $=0.491, p<0.01)$.

In order to shed more light on the specific nature of the interaction effects, Jose (2008) advances the idea of generating graphs using ModGraph programme.
According to Jose (2008), the conditions for the statistical significant interaction to occur are (a) the regression lines must not be parallel meaning that the regression lines must exhibit different slops or gradients and (b) the effect of one of the variables must differ depending on the level of the other variable, that is the magnitude of an effect should be greater at one level of the variable than at another.

\section{Organizational learning}

Figure 1 proves that the effect of organizational learning on market performance differ depending on the levels of market orientation. The magnitude effect of organizational learning on market performance is greater at high levels of market orientation than at low levels of market orientation. The results support $\mathrm{H}_{3}$ as the magnitude of an effect is greater at one level than at another level proving that a significant interaction exists, which is consistent with Aiken and West (1991) and Jose (2008).

\section{DISCUSSION AND MANAGERIAL IMPLICATIONS}

This study empirically examined the relationship between organizational learning and market performance $\left(\mathrm{H}_{1}\right)$, the extent to which each of the organizational learning strategy namely: adaptive learning, generative learning and triple-loop learning is important in influencing market performance $\left(\mathrm{H}_{2}\right)$ and the interaction effect of market orientation in the relationship $(\mathrm{H} 3)$.

To achieve these relationships and benefit from them managerial support is vital together with an appropriate learning infrastructure and market-based organizational culture. Market-based organizational culture serves in guiding employees' behaviours and attitudes to appreciate the value and importance of this relationship.

Non-marketing staff may try to distance themselves from learning about market trends unless management guides and shapes the behaviours and attitudes of all employees. Such a culture imposes coherence, order and meaning to the need for interpreting market trends. For example, organizations with a low level of market performance may focus on improving organizational learning process by developing strategic training activities that enrich customer satisfaction practices, put in place better systems to store, manage and interpret marketbased knowledge in all sections of the organization.

Management should be open to new ideas and, to a certain extent tolerate some risk experimentation with some allowance for failure (Prugsamatz 2010). In this way, management promotes positive attitudes towards learning and marketing.

The results indicated that when an organization depends on the adaptive learning style, there is no significant effect on market performance. With the generative 
Table 3. Hierarchical regression analysis with market performance as the dependent variable.

\begin{tabular}{lcccc}
\hline Variable & Model 1 & Model 2 & Model 3 & Model 4 \\
\hline (Constant) & $4.86^{* *}$ & $3.78^{* *}$ & $1.56^{* *}$ & $1.98^{* *}$ \\
Type of industry & -0.092 & $-0.083^{* *}$ & -0.019 & -0.022 \\
Number of employees & $-0.335^{\star *}$ & $-0.203^{* *}$ & -0.050 & -0.049 \\
Organizational tenure & $0.172^{* *}$ & $0.101^{* *}$ & 0.039 & 0.049 \\
Organizational learning & & $0.405^{\star *}$ & $0.198^{* *}$ & $0.170^{* *}$ \\
Market orientation & & & $0.245^{\star *}$ & $0.203^{\star *}$ \\
OLxMO & & & 0.575 & $0.333^{\star *}$ \\
R & 0.320 & 0.488 & 0.331 & 0.491 \\
R square & 0.103 & 0.238 & 0.325 & 0.486 \\
Adjusted R square & 0.099 & 0.233 & 105,24 & 90.69 \\
F - statistics & 23.18 & 44.72 & 0.093 & 0.160 \\
R Square Change & 0.103 & 0.135 & 253.02 & 88.28 \\
F change-statistics & 23.18 & 95.58 & 0.000 & 0.000 \\
Sig & 0.000 & 0.000 & 0.000 & 0.000 \\
Sig F Change & 0.000 & 0.000 & & \\
\hline
\end{tabular}

$\mathrm{n}=438$ Standardized regression coefficients are reported. ${ }^{* *}$ Regression is significant at the 0.01 level, ${ }^{*}$ regression is significant at the 0.05 level.

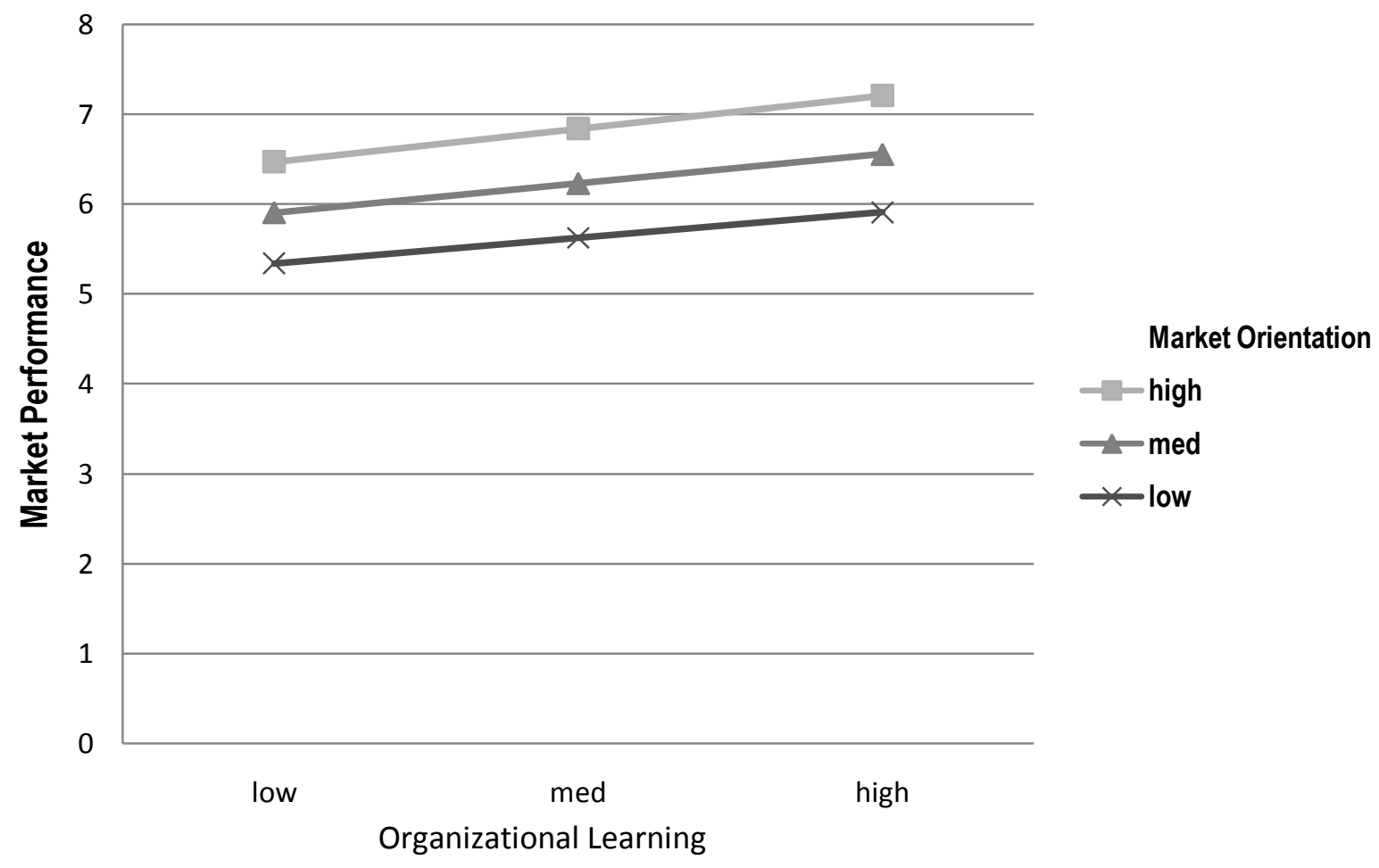

Figure 1. Interaction effect of organizational learning and market orientation on market performance.

learning style a positive significant contribution to market performance is achieved and contribution is highly improved with triple-loop learning style. For managers, this is in the form of a continuum with adaptive learning as the low level of learning at one end and on the other end is triple-loop learning - the higher-order level of learning. Managers should strive to move their organizations from the lower end of the continuum where 
the impact to market performance is minimal to the higher level of the continuum.

Huber (1991) introduced the concept of unlearning, pointing out the fact that the difficulty to forget and unlearn the way things are done in organizations is one of the major barriers to learning and change as most employees may be inward-looking, preferring to perform tasks which are routine in order to keep the status quo.

An organization operating at the adaptive level of learning will in most cases focus on survival only and not much on market performance superiority. To move into a more competitive position the organization has to upgrade its learning capabilities to the generative learning level. At the generative learning level routines and the status quo are constructively challenged in order to effect necessary adjustments to improve on the market performance.

According to the results of this study, when the generative learning level is attained, the impact of organizational learn on market performance increases as the organization test potential ideas and replace old rules with new ones. The organization is now more competitive in the marketplace and should start to benefit in terms such as profits, market share and customer satisfaction.

In order to offer products and services that contribute to operational efficiency and strategic effectiveness leading to better market performance, an organization will have to apply triple-loop learning. This level of organizational learning focuses on innovativeness to enhance superior market performance in the future marketplace.

The competitiveness of the organization is now at market leadership or close to market leaders. This level requires continuous re-examination of how the organization's mission, vision, culture, offerings, the process used, structures and systems are in conformity with the future marketplace.

When organizational learning process is inclusive of market-based information, it leads to what Morgan and Turnell (2003: 256) refer to as 'a process of marketbased organizational learning'; an indicative of a market driven learning organization. This positive relationship enables the organization to learn and act proactively to market changes by facilitating radical and incremental changes that allow the organization to achieve better marketplace results (Mupepi, 2008).

Market-based organizational learning enables the organization as a whole to focus on satisfying customer needs (Levinthal and Rerup, 2006); which in turn promotes creativity, innovativeness, risk-taking and experimentation which are closely connected with competitiveness in the market place. Employees become conscious in developing those skills that identify market opportunities and reduce on threats that may negatively impact market performance. This means that it is possible to reduce market performance negative gaps by focusing on learning from external information. A positive approach to this relationship is helpful for an organization to be skillful at problem solving, experimenting with new approaches, learning from their own experience, following the best practices of others and transferring knowledge quickly and efficiently throughout the organization.

Leaders must be models for new market-based learning behaviours and norms; they must develop and communicate a consistent learning vision and promote learning initiatives in a manner that helps organization members focus, allocate resources, and choose or reject different opportunities (Bui and Baruch, 2010).

In the case of motivation, employees need to feel valued and appreciated not only for visible output or production but also for learning on the job, and generating, and generalizing knowledge that improves the learning curve of the organization. According to James-Gordon and Bal (2003), employees, especially salespeople, should be given more control and responsibility over their everyday tasks, self-development and their job-related training in order to enhance their self-directedness in learning.

\section{Conclusion}

There is need for organizations to link their organizational learning activities with market-based information in order to improve on their market performance. It is better to focus on higher levels of learning combined with a market orientation approach. These developments requires an organizational culture that challenges the status quo on a number of issues, accepts openness to new ideas, practices unlearning, and can takes on risks for purposes of learning and innovativeness.

Organizations are in better positions to develop competences that are both organization-based and marketplace-based to undermine competitor's innovation, making competition irrelevant and open up new market opportunities.

\section{FUTURE RESEARCH}

We acknowledge some limitations in this research study especially that instead of a cross-sectional design, a longitudinal study may be carried out. For future research, this study can be repeated in a different environment especially that we have tried to present a detailed methodology used for this study. This is important as there are still scare empirical studies that have examined this relationship to enable practitioners evaluate their organizational learning outcomes in terms of market performance. Also, other than combining both manufacturing and service firms, research studies can take one sector at a time. Other important constructs of market performance such as market share; customer retention and customer complaints can also be tested. 


\section{REFERENCES}

Akgün AE, Lynn G, Byrne J (2003). Organizational learning: A sociocognitive framework. Hum. Relat. 56(7):839-868.

Argyris C (1999). On Organizational Learning, Blackwell Cambridge MA.

Argyris C, Schon DA (1996). Organizational Learning II: Theory, Methods and Practice, Addison-Wesley, Reading M.A.

Argyris C, Schon DA (1978). Organizational Learning: A Theory of Action perspective Addison-Wesley, Reading M.A.

Baker WE, Sinkula JM (2002). Market orientation, learning orientation and product innovation: delving into the organization's black box. J. Market-focused Manag. 15(1):5-23.

Baker WE, Sinkula JM (1999). The synergistic effect of market orientation on organizational performance, J. Acad. Mark. Sci. 27(4):411-427.

Bell SJ, Whitwell GJ, Lucas BA (2008). Schools of thought in organizational learning, J. Acad. Mark. Sci. 30(1):70-86.

Bennett R (1998). Charities, organizational learning and market orientation. J. Market. Pract: Appl. Market. Sci. 4(1):5-25.

Bontis N, Crossan MM, Hulland J (2002). Managing an organizational learning system by aligning stocks and flows. J. Manag. Stud. 39(4):437-469.

Briggs BR (2009). Issues affecting Ugandan indigenous entrepreneurship in trade. Afr. J. Bus. Manag. 3(12):786-797.

Brockmand B, Morgan F (2003). The role of existing knowledge in new product innovativeness and performance, Decision Sci. 32(2):385419.

Bui H, Baruch $Y$ (2010). Creating learning organizations: a systems perspective. Learn. Organis. 17(3):208-227.

Burgoyne J (1995). Feeding minds to grow the business, People Manag. 10(2):91-109.

Chang WA, Ahn J (2005). Product and Process knowledge in the performance- orientated knowledge management approach, $\mathrm{J}$. Knowl. Manag. 9 (4):114-132.

Chaston I, Badger B, Sadler-Smith E (1999). Organizational learning: research issues and application in SME sector firms. Int. J. Entrep. Behav. Res., 5(4):191-203.

Chattopadhyay P, Glick W, Miller CC, Huber G (1999). Determinants of executive beliefs: comparing functional conditioning and social influence, Strategic Manag. J. 20(8):763-789.

Day GS (1999). The Market driven Organization, New York, Free Press.

Day GS (1994). The capabilities of the market-driven organizations". J. Mark. 58(4):37-52.

Delaney JT, Huselid MA (1996). The impact of human resource management practices on perceptions of performance in for-profit and non-profit organizations, Acad. Manag. J. 39:949-69.

Deshpande R, Farley JV, Webster F (1993). Corporate culture, customer orientation and innovativeness in Japanese Firms: a quadrad analysis, J. Mark. 57(1):23-37.

Dixon NM (1992). Organisational learning: a review of the literature with implications for HRD professionals. Hum. Resour. Dev. Q. 31(1):2949.

Dodgson M (1993). Organizational learning: a review of some literature. Organ. Stud. 14(3):375-394.

Ellinger AD, Ellinger AE, Yang B, Howton $S$ (2002). The relationship between the learning organization concept and financial performance: an empirical assessment. Hum. Resour. Dev. Q. 13(1):5-21.

Foley A, Fahy J (2009). Seeing market orientation through a capabilities lens. Eur. J. Market. 43(1/2):13-20.

Foley A, Fahy J (2004). Towards a further understanding of the development of market orientation in the firm: a conceptual framework based on the market-sensing capability. J. Strat. Mark. 12(4):219-230.

Frost TS, Birkinshaw JW, Ensign PC (2002). Centers of excellence in multinational corporations". Strat. Manag. J. 23(11):997-1018.

Garnett JL, Marlowe J, Pandey SK (2008). Penetrating the performance predicament: communication as a mediator or moderator of organizational culture's impact on public organizational performance. Public Admin. Rev. 68(2):266-281.

Hancott DE (2005). The relationship between transformational leadership and organizational performance in the largest public companies in Canada, Unpublished doctorial dissertation, Capella University, Minneapolis MN.

Hillman AJ, Keim GD (2001). Shareholders and social issue, Strat. Manag. J. 22(2):125-139.

Ho L.-A. (2008). What affects organizational performance? The linking of learning and knowledge management, Industrial Management \& Data Syst. 108(9):1234-1254.

Hoe SL, McShane S (2010). Structural and informal knowledge acquisition and dissemination in organizational learning: An exploratory analysis. Learn. Organ. 17(4):364-386.

Hooley GJ, Greenly GE, Cadogan JW, Fahy J (2005). The performance impact of marketing resources. J. Bus. Res. 58(1):35-50.

Huber GP (1991). Organizational learning: the contributing processes and the literatures. Organ. Sci. 2:88-115.

Hunt SD, Morgan RM (1995). The competitive advantage theory of competition, J. Mark. 59:1-15.

James-Gordon Y, Bal J (2003). The emerging self-directed learning methods fordesign engineers. Learn. Organ. 10(1):63-69.

Jaworski B, Kohli AK, Sahay A (2000). Market-driven versus driving markets, J. Acad. Mark. Sci. 28(1):45-54.

Jiménez-Jimenez D, Valle RS, Hernandez-Espallardo M (2008). Fostering innovation: The role of market orientation and organizational learning, Eur. J. Innov. Manag. 11(3):389-412.

Jose EP (2008) Welcome to the Moderation/Mediation Help Centre, School of Psychology Victoria University of Wellington Version 2.0.

Jyothibabu C, Farooq A, Pradhan BB (2010). An integrated scale for measuring an organizational learning system. Learn. Organ. 17(4):303-327.

Kohli AK, Jaworski B, Kumar A (1993). MARKOR: A measure of market orientation. J. Market. Res. 30(Nov.):467-477.

Kohli AK, Jaworski BJ (1990). Market orientation: the construct, research proposition and managerial implications. J. Mark. 54:1-18.

Konidari V, Yvan A (2006). From TQM to learning organization: Another way for Quality Management in educational institutions, Int. J. Qual. Reliab. Manag. 23(1):8-26.

Krejcie R, Morgan D (1970). Determining sample size for research activities. Educ. Psychol. Meas. 30:607-610.

Kuada $J$ (2010). Culture and leadership in Africa: a conceptual model and research agenda. Afr. J. Econ. Manag. Stud. 1(1):9-24.

Lei D, Hitt M, Bettis R (1996). Dynamic core competences through meta-learning and strategic context. J. Manag. 22(4):549-569.

Levinthal D, Rerup C (2006). Crossing an apparent chasm: bridging mindful and less-mindful perspectives on organizational learning Organ. Sci. 17(4):502-513

Mason KJ, Harris LC (2006). Market orientation emphases: an explanation of macro, meso, and micro drivers. Market. Intell. Plann. 24(6):552-571.

Marquadt MJ (1996). Building the Learning Organization. McGraw-Hill New York, NY.

McGuinness T, Morgan RE (2005). The effect of market and learning orientation on strategy dynamics: The contributing effect of organizational change capability. Eur. J. Mark. 39(11/12):1306-1326.

Menguc B, Ash S (2006). Creating a firm-level dynamic capability through capitalizing on market orientation and innovativeness. Acad. Market. Sci. J. 34(1):63-73.

Michna A (2009). The relationship between organizational learning and SME performance in Poland". J. Eur. Industr. Train. 33(4):356-370.

Morgan R, Turnell CR (2003). Market-based organizational learning and market performance gains. Br. J. Manag. 14:255-274.

Mostafa M (2005). Factors affecting organizational creativity and innovativeness in Egyptian business organizations: an empirical investigation. J. Manag. Dev. 24 (1):7-33.

Mupepi MG, Mupepi SC, Tenkasi RV, Jewell G (2008). Precision in managing organizational change: identifying and analyzing needs using social constructs, Int. J. Manag. Pract. 3(2):150-163.

Narver JC, Slater SF (1990). The effect of market orientation on business profitability". J. Mark. (October), pp. 20-35.

Narver JC, Slater SF, MacLachlan D (2004). Responsive and proactive market orientation and new product success. J. Prod. Innov. Manag. 12(5):334-344.

Neuman L (2006). Social Research Methods: Qualitative and 
Quantitative approaches. 6ed, Pearson International, London.

Nevis E, Dibella A, Gould J (1995). Understanding organizations as learning systems. Sloan Manag. Rev. 36(2):73-85.

Nunnally JC (1967). Psychometric Theory, New York: McGraw Hill.

Nunnally JC (1978). Psychometric Theory $2^{\text {nd }}$ edition, New York: McGraw Hill.

O'Keeffe T, Harington D (2001). Learning to learn: an examination of organizational learning in selected Irish Multinationals. J. Eur. Ind. Train. 25(2/3/4):137-147.

Olavarrieta S, Friedmann R (2007). Market orientation, knowledgerelated resources and firm performance. J. Bus. Res. 61(6):623-630.

Politis JD (2005). QFD organizational creativity and productivity. Int. J. Qual. Reliab. Manag. 22(1):59-71.

Prugsamatz $R$ (2010). Factors that influence organization learning sustainability in non-profit organizations. Learn. Organ. 17(3):243267.

Racel CO, Chaikittisilpa C, Thoumrungroje A (2007). Market orientation, international business relationships and perceived export performance". Int. Mark. Rev. 24(2):144-163.

Ruekert R (1992). Developing a market orientation: an organizational strategy perspective. Int. J. Res. Market. 9(3):225-245.

Sadler-Smith E, Gardiner P, Badger B, Chaston I, Stubberfield J (2003). Using collaborative learning to develop small firms, Human Resource Development International, 3(3):285-306.

Saru E (2007). Organizational Learning and HRS: how appropriate are they for small firms? J. Eur. Indust.Train. 31(1):36-51.

Schium G, Lerro A (2008). Intellectural capital and company's performance improvement. Meas. Bus. Excell. 12(2):3-9.

Senge P (1990). The Fifth Discipline: The Art and Practice of the Learning Organization, Doubleday New York NY.

Shapiro BP (1988). What the hell is market orientation? Harvard Bus. Rev. 66(6):119-125.

Shoham A, Rose GM, Kropp F (2005). Market orientation and performance: a meta-analysis. Market. Intell. Plann. 23(5):435-454.

Slater SF, Narver JC (1999). Market orientation is more than being customer-led. Strateg. Manag. J. 20(12):1165-1170.

Slater SF, Narver JC (1995). Market orientation and the Learning Organization. J. Mark. 59(July):63-74.
Spanos YE, Lioukas S (2001). An examination into the causal logic of rent generation: contrasting Porter's competitive strategy framework and the resource-based perspective. Strateg. Manag. J. 22(10):907934.

Steer RM (1975). Problems in the measurement of organizational effectiveness, Admin.Sci. Q. 20(4):546-558.

Subramanian R, Kumar K, Strandholm K (2009). The role of organizational competencies in the market-orientation-performance relationship: An empirical analysis, Int. J. Com. Manag. 19(1):7-26.

Tippins MJ, Sohi RS (2003). IT competency and firm performance: is organizational learning a missing link. Strat. Manag. J. 24(8):745-761.

Uganda Bureau of Statistics (UBOS) (June, 2007). Report on the Uganda Business Register 2006/07.

Wang CL, Ahmed PK (2003). Organizational learning: A critical review. Learn. Organ. 10(1):8-17.

Weldy TG, Gillis WE (2010). The learning organization: variations at different organizational levels. Learn. Organ. 17(5):455-470.

Westphal JD, Frederickson JW (2001). Who directs strategic change? Director experience, the selection of new CEOs and change in corporate strategy. Strat. Manag. J. 22(12):1113-1138.

Werr A, Blomberg J, Lowstedt J (2009). Gaining external knowledgeboundaries in managers knowledge relations. J. Knowl. Manag. 13(6):448-463.

Whittington D, Dewar T (2004). A strategic approach to organizational learning. Ind. Commercial Train. 36(7):265-268.

Yang $J$ (2007). The impact of knowledge sharing on organizational learning and effectiveness. J. Knowl. Manag. 11(2):83-90.

Yeo R (2003). Linking organizational learning to organizational performance and success: Singapore case studies. Leaders. Organ. Dev. J. 24(2):70-83

Zhou Y, Chao P, Huang G (2009). Modeling market orientation and organizational antecedents in a social marketing context: Evidence from China. Int. Mark. Rev. 26(3):256-274. 